Bodil Halvars är lektor i didaktik vid Barn- och ungdomsvetenskapliga institutionen vid Stockholms universitet. Med bakgrund som förskollärare och lärarutbildare står förskoledidaktik riktat mot naturvetenskap och hållbar utveckling i förskolan i fokus. Hennes övriga forskningsintressen är barns etiska möten samt lek.

BODIL HALVARS

Barn- och ungdomsvetenskapliga institutionen vid Stockholms universitet, Sverige

bodil.halvars@buv.su.se

\title{
Barns frågor under en utforskande process kring träd
}

\begin{abstract}
The aim of the study is to scrutinize children's meaning-making in a tree-project during one year in a preschool class. The purpose with this article is to shed light on what happens in children's encounters with the trees and how an exploratory approach might encompass children's own questions and working theories.
\end{abstract}

By mapping the children's explorative process from the Deluzian concept learning as a relational field of potentiality (Dahlberg \& Elfström, 2014), the connections are identified and analyzed. The data has been generated through ethnographical methods: participant observations, focus groups and stimulated recall. The children's aesthetic works and the concluding exhibition with additional walks are also part of the data generating.

The mapping of the tree-project makes the meaning-making visible, where the children's questions center on complex issues with further connections to ecological issues and sustainability. The driving force of the project is the questions that the children pose, while the pedagogues support their explorations in order to deepen and develop the learning possibilities.

\section{INLEDNING}

I föreliggande artikel beskrivs ett utsnitt från en studie av ett ettårigt projekt där en förskoleklass utforskar träd. Då träd och andra växter på många sätt skapar förutsättningar för livet på jorden kan ökade kunskaper inom detta område ses som fundamentala, särskilt i den antropocena tidsålder vi lever i då miljö- och klimathot ställer frågor kring ekologi och hållbar utveckling på sin spets (Cole \& Malone, 2019). Pedagogernas syfte med trädprojektet var att väcka barnens nyfikenhet och intresse kring ett gemensamt ämnesinnehåll och tillsammans undersöka det närmare. I förskoleklassens uppdrag framgår tydligt att barnen ska ges möjligheter att utforska natur- och samhällsfrågor och påbörja ett samtal kring "olika företeelser och samband i omvärlden" och genom tillgång till estetiska uttrycksformer ges förutsättningar "att kunna tänka, lära och kommunicera i olika sammanhang och 
för skilda syften” (Skolverket, 2017:21). Genom ett utforskande arbetssätt var pedagogernas intention att möjliggöra detta. Att seriöst ta sig an barns frågor är en uppfordrande uppmaning som Olsson (2013) adresserat till förskolefältet. Men vad händer när barns frågor och teorier kring ett ämnesinnehåll är själva utgångspunkten och drivkraften? Vilka frågor uppstår hos barnen och hur utmanas de vidare? Dessa forskningsfrågor är fokus i denna artikel om barns frågor kring träd under en utforskande process.

\section{ATT UTFORSKA TRÄDENS LIV}

Barnen i den förskoleklass där studien är förlagd ombads av sina blivande pedagoger att ta med sig "någonting som kommer från ett träd" till terminsstarten. Barnen hade med sig barr, kottar, frukter, frön, nötter, kärnor, blad, barkbitar, pinnar samt en gren med bävergnag, en juiceförpackning och en fårskalle (som hade hängt i ett träd). Att på så sätt rikta uppmärksamheten mot träd redan innan projektstarten blev början på ett utforskande av träd utifrån olika aspekter.

Trädens fundamentala betydelse för många levande varelser kan direkt kopplas till aktuella miljöoch hållbarhetsfrågor. För att kunna fördjupa sig i dessa frågor behövs specifika kunskaper kring naturens kretslopp och ekologi, samt nyfikenhet och respekt inför liv i alla dess former. Hur man kan arbeta för att undvika människors oförmåga att uppfatta växter i den omgivande miljön, s.k. växtblindhet (plant blindness) (Wandersee \& Schussler, 1999) och istället öka förmågan att verkligen se växter och deras betydelse för livet på jorden är en aktuell forskningsfråga (Calvo, Gagliano, Souza \& Trewavas, 2020; Nyberg, Brkovic \& Sanders, 2019; Sanders, 2019).

Att se träd som organismer utifrån deras egna förutsättningar, icke-mobila och med ett annat förhållande till tid, innebär en perspektivförskjutning. Forskning utifrån ett växtperspektiv visar att träd inte enbart är passiva och icke mottagliga för kommunikation utan i allra högsta grad levande, kommunicerande organismer (Gagliano, Ryan \& Vieira, 2017). Den inre kommunikationen reglerar de egna funktionerna med elektriska, hydrauliska och kemiska signaler vid exempelvis fotosyntes och vattenförsörjning. Forskning har nyligen funnit att träd har en form av puls som man tror är en del av trädets vattenförsörjning (Zlinszky \& Badford, 2018). Den mer utåtriktade kommunikationen med omgivningen består av ett ständigt pågående utbyte med andra träd och växter, djur och insekter. Forskning pågår kring växters inbördes kommunikation via vibrationer, ljus- och ljudvågor (Gagliano et al., 2017; Schöner, Simon \& Schöner, 2016) samt deras aktiva deltagande i de ekologiska system de ingår i (Gagliano et al., 2017). Med hjälp av doftämnen lockar träd till sig insekter och andra djur (Mancuso \& Viola, 2015). Trädens subtila kommunikationsformer blir dock många gånger synliga först efter en längre tid, vissa arter undviker exempelvis kronkollision genom att deras trädkronor inte nuddar vid varandra trots att de växer tätt (crown shyness).

En viktig del av trädens liv pågår under markytan, de mikrobiologiska förmultningsprocesser som trädens löv involveras i sker till stora delar under jord och forskning pågår kring hur träden via sina rötter kommunicerar med andra träd och levande organismer (Rassmann \& Turlings, 2016). De flesta träd är även beroende av så kallade mykorrhiza-symbios där träd och svamp kompletterar varandras upptag av näring; svampen gör vatten och mineraler mer tillgängligt för trädet, medan trädet i sin tur bidrar med energi till svampen i form av sockerarter (Thomas, 2000). Genom mykorrhizan pågår även en kommunikation med andra träd, via utbytet kan olika trädslag exempelvis nätverka (wood wide web) kring förändrade förutsättningar (Simard, 2012).

Träden ingår följaktligen alltid i ekologiska system där ett ständigt utbyte av energi och materia sker mellan de levande organismerna och den omgivande miljön. De ekologiska systemen är oftast inte tydligt avgränsade utan öppna mot omvärlden och det pågående skeendet och omfånget varierar från mikronivå till global nivå. Biosfären är summan av alla ekologiska system, ett enormt jordsystem som består av ett oändligt antal ekosystem. 


\section{LÄRANDET SOM ETT RELATIONELLT POTENTIALITETSFÄLT}

Att följa ett årslångt trädprojekt i en förskoleklass kräver översikt men samtidigt avgränsning. Genom att göra en kartläggning med utgångspunkt från det filosofiskt förankrade begreppet lärandet som ett relationellt potentialitetsfält har intentionen varit att studera de frågeområden som uppkommit under trädprojektets framväxt. Begreppet har sitt ursprung i ett relationellt perspektiv där lärandet ses växa fram genom ett obegränsat antal kopplingar mellan förskolans aktörer (barn, pedagoger, vårdnadshavare), miljön (utom- och inomhus), material (estetiskt, återvunnet och naturmaterial) och ett ämnesinnehåll (exempelvis naturvetenskap) (Dahlberg \& Elfström, 2014). Ett gemensamt problemfält konstrueras, där frågor och problemställningar som saknar på förhand givna svar utgör drivkraften i ett fortsatt utforskande (Elfström, 2013). I problemfältet ryms olika krafter och förbindelser; genom att uppmärksamma de händelser (events) som sker kan den potentialitet som uppstår ges plats, utan att direkt tolkas utifrån igenkänning, kategorisering eller representation (Unga, 2013). Genom Deleuzes event-begrepp synliggörs att barnens meningsskapande producerar såväl som reproducerar kunskap samt att deras frågor är expanderande till sin art: "[...] children's questions are always larger, much more playful and at the same time much more serious than we imagine" (Olsson, 2013:230).

Studier av dessa problemfält inrymmer ett rhizomatiskt perspektiv, vilket innebär att uppmärksamhet riktas mot den rörelse och vitalitet som finner nya oväntade vägar vid barnens meningsskapande (Elfström, 2013; Olsson, 2009). Rhizom-begreppet formuleras av Deleuze och Guattari (1980/2015) som ett system med en vibrerande, mångfaldig intensitet, där oförutsägbara sammankopplingar uppstår utan någon egentlig början eller slut. Det rhizomatiska perspektivet kan därför användas för att synliggöra lärprocesser och meningsskapande utan ett orsak-verkan-resonemang (jfr. Colebrook, 2010). Med lärprocessen i fokus kan dock ett specifikt lärande eller ett visst ämnesinnehåll stundtals vara svårt att särskilja; kopplingarna ger plats för ny, planerad eller icke-planerad, kunskap och mening att skapas (Johansson, 2015).

\section{ETT UTFORSKANDE ARBETSSÄTT UR ETT FÖRSKOLEDIDAKTISKT PERSPEKTIV}

Inom viss förskoledidaktisk forskning har den rhizomatiska utgångspunkten kopplats till ett transdisciplinärt perspektiv på lärande (Elfström, 2013). Lärandet har undersökts från ett multipelt perspektiv där fokus varit tillblivandet snarare än varandet, vilket öppnar för ett undersökande av händelser och rörelser som uppstår i pedagogiska praktiker (Olsson, 2009).

Utifrån ett mer posthumanistiskt perspektiv med neomaterialistiska inslag har Green och Duhn (2015) följt barns intra-aktion med icke-mänskliga krafter (väder) och materia (jord, växter, djur, etc.) under deras arbete i skolträdgårdar. Genom att fokusera materiell agens snarare än barnens individuella lärande synliggör studien, förutom den potentiella fördjupningen inom odling, ett lärande kring hållbarhetsfrågor och matproduktion. Även Rautio (2013) har i sin forskning närmat sig frågor kring hur barn tar del av naturen genom att studera deras intra-aktion med stenar, pinnar, måsar och hur dessa möten kan utmana tankar och praxis inom miljöundervisning och lärande för hållbar utveckling (Rautio, Hohti, Leinonen \& Tammi, 2017). Genom enkla vardagshändelser fångas komplicerade frågor kring människans del i naturen upp. Taylor (2017) argumenterar för pedagogik som utgår från en gemensam värld (common-world-pedagogies) och tydligare svarar upp mot accelererande miljö- och klimatfrågor genom att optimera barns relationer med sin omvärld, till människor och andra levande varelser, platser och ting.

Vid ett utforskande arbetssätt i förskolans kontext, där barnens frågor och provisoriska teorier driver processen framåt, är pedagogernas aktiva lyssnande nödvändigt för att uppfatta det som sker i stunden. Genom ett tydligt förskoledidaktiskt syfte parallellt med ett ämnesinnehållsligt fokus kan lyssnandet riktas mot barnens meningsskapande (Svedäng, Halvars, Elfström \& Unga, 2018). I ett förskoleprojekt om biologisk mångfald påvisar Caiman och Lundegård (2015) hur kombinationen av pedagogernas varsamma lyssnande och medforskande förhållningssätt möjliggör för ett naturvetenskapligt utforskande och fördjupning inom ekologi. Pedagogerna möter barnens intresse kring ekolo- 
giska system med produktiva frågor och nya utmaningar. I en annan studie har Sundberg, Areljung och Ottander (2019) studerat naturvetenskapliga aktiviteter i förskolan utifrån ett verksamhetsteoretiskt perspektiv och identifierat hur en mångdimensionell naturvetenskaplig undervisning kan inrymma barns känslor, fantasi och lek. Utifrån ett hållbarhetsperspektiv diskuterar de vidare förskollärarens roll att skapa möjligheter för barnens agens, naturkontakt och problemlösning. Vikten av att ge förskolebarns fantasi, föreställningsförmåga och kreativitet utrymme kan kopplas till potentiella lösningar på framtidens hållbarhetsfrågor (Caiman \& Lundegård, 2018). Genom ett experimentellt förhållningssätt med en estetisk ingång och ett sinnligt närmande kan den estetiska dimensionen i det utforskande arbetet öppna för en ökad känslighet och förmåga att finna nya lösningar (jfr. Dahlberg, Olsson \& Theorell, 2016).

\section{BARNS FRÅGOR OCH PROVISORISKA TEORIER}

Utifrån ett pragmatiskt perspektiv studerar Caiman förskolebarns meningsskapande kring biologisk mångfald och hållbarhetsfrågor och formulerar lärandet som "en öppen 区tillblivelseakt' " (Caiman, 2015:76), där ämnesinnehållet konstitueras under den utforskande processen. Det utforskande arbetssättet i förskolan är inte direkt jämförbart med det som bedrivs i en skol- eller forskningskontext då fler aspekter, såsom språk och estetik liksom att barn gör naturvetenskap, inbegrips i den process där barn och pedagoger involveras (Caiman \& Lundegård, 2015). Caiman och Lundegård lyfter barnens möjligheter till agens kopplat till pedagogernas inlyssnande förhållningssätt som didaktiska utgångspunkter för ett fördjupat utforskande.

Barns frågor i relation till pedagogers frågor och svar kan ses som uttryck för barns perspektiv och samtidigt ge underlag för pedagogernas didaktiska val menar Thulin (2010). Barnens frågor utgår från tidigare erfarenheter och pågående lärande där bemötande och uppföljning av frågorna kan ses som en didaktisk utmaning. I Thulins studie framkommer att barnen är "innehållsfokuserade", deras frågor har främst inriktning mot vetande, samt att de söker lösningar på sina problem såväl individuellt som tillsammans (Thulin, 2010). Utifrån ett naturvetenskapligt perspektiv har frågor och vardagssituationer i förskolan, där förskollärare uppmärksammat potentiella lärtillfällen inom kemi och fysik, analyserats av Hansson, Löfgren och Pendrill (2014). Mängden av situationer/frågor samt den innehållsliga bredden visar på att förskollärarna identifierar naturvetenskapliga frågor och situationer i förskolans vardag och att barnen är "innehållsinriktade". Vikten av att kunna identifiera och välja bland vardagens potentiella lärandesituationer för att optimera barns fortsatta naturvetenskapliga erfarande och lärande framhålls (Hansson et al., 2014).

I projekt med naturvetenskapligt fokus kommer barnen ofta in på existentiella frågor. När HalvarsFranzén (2010) utifrån ett relationsetiskt perspektiv studerat barns möten med djur kom frågorna att cirkla kring djurens livsbetingelser, liv och död samt rena värdefrågor. I ett förskoleprojekt som startade med ett rådjurskadaver mynnade barnens frågor om förmultning och mögel efterhand ut i frågeställningar kring pånyttfödelse (Elfström, 2013). I projektet följde pedagogerna genom den pedagogiska dokumentationen barnens utforskande och identifierade flöden av frågor och problem som intresserade dem inom det gemensamma problemfältet. Under den utforskande processen blev barnens frågor och pedagogernas fortsatta erbjudanden och utmaningar parallella processer vilket möjliggjorde problemfältets expansion.

I tidigare forskning beskrivs barns provisoriska teorier (working theories), som tentativa, spekulerande och ändamålsenliga "mini-teorier" som växer fram ur den kunskap och de erfarenheter som barn erfar i sin vardag (Hedges, 2014; Hedges \& Cooper, 2017). När barnens förklaringsmodeller möter pedagogernas undervisningsstrategier uppstår situationer som ställer särskilda krav på pedagogernas bemötande och kunnande (Areljung, 2017; Areljung \& Kelly-Ware, 2016). Barns intresse för en fråga tar sig olika utryck och pedagogerna behöver utröna den specifika frågan som intresserar barnen för att kunskaperna ska kunna kompliceras och fördjupas. I en studie som särskilt fokuserat pedagogiska frågor och dilemman kring provisoriska teorier har Davis och Peters (2012) undersökt denna växelverkan mellan intresse och expertis. 
Olika aspekter av barns utforskande och provisoriska teorier har studerats i tidigare forskning. Dock efterfrågas alltjämt vidare forskning kring yngre barns ämnesinnehållsliga fokus, exempelvis naturvetenskapliga fenomen och ekologiska samband (Elfström, 2013; Caiman \& Lundegård, 2015). Föreliggande kartläggning kan ses som ett tillägg till kunskapsområdet.

\section{SYFTE OCH FRÅGESTÄLLNINGAR}

Genom att undersöka vilka ämnesinnehållsliga aspekter kring träds liv och ekologi som framträder vid ett utforskande arbetssätt är syftet med studien att synliggöra vad som sker när sexåriga barn möter träd och hur ett meningsskapande kan växa fram. I en kartläggning av problemfältets expansion under ett ettårigt trädprojekt följs barnens frågor kring träd genom att identifiera och analysera de kopplingar som framträder. Studien kan ses som ett bidrag till diskussionen om yngre barns frågor kring ekologi och hållbarhet som tar sin utgångspunkt i ett naturvetenskapligt utforskande, där framtida frågor och lösningar inte alltid kan förutses (Caiman \& Lundegård, 2018; Somerville, 2018; UNESCO, 2017).

Frågeställningarna fokuserar barnens utforskande av träd:

- Vilket meningsskapande växer fram i barnens möten med träd? Vilka är barnens egna frågor?

- Hur öppnar ett utforskande arbetssätt upp för närmandet av frågor som rör ekologi och hållbarhet för yngre barn?

\section{METOD}

Föreliggande artikel behandlar ett utsnitt från en studie av ett trädprojekt i två förskoleklasser. Studien sträckte sig över ett läsår, höst- och vårtermin, där barnens naturvetenskapliga och estetiska utforskande av träd fortgick såväl i klassrum som på skolgård samt under återkommande besök i en närliggande skog. En avgränsad del av studien kartläggs i artikeln: utvalda delar av den utforskande processen i en av de två förskoleklasserna, med fokus på det meningsskapande som växte fram i barnens möte med träd.

\section{Datagenerering och urval}

Studien har en etnografisk ansats där datagenereringen spänner över ett år, dvs. hela den avgränsade tid som barngruppen tillbringade i förskoleklass. Den etnografiska ingången möjliggör en bred datagenerering där deltagande observationer, gåturer och barnens alster synliggör frågornas framväxt (jfr. Clark, Flewitt, Hammersley \& Martin, 2014; Hammersley \& Atkinsson, 2019).

Observationer och gåturer har filmats med en handhållen videokamera med kompletterande fältanteckningar. Den pedagogiska miljön och barnens alster har fotograferats vid återkommande tillfällen under läsåret. Pedagogernas processberättelser samt fokussamtal med stimulated recall har spelats in via digital ljudinspelare och kompletterats med stödanteckningar (jfr. Halvars-Franzén, 2010). De filmade sekvenserna och de ljudinspelade samtalen har sedan lyssnats igenom vid ett flertal tillfällen och valda delar har sedan transkriberats.

Förskoleklassen benämns i framställningen av de empiriska resultaten som FY. Barngruppen bestod av 28 sex-sjuåriga barn där 3 förskollärare följde barnen under hela dagarna. Utifrån en etnografisk ansats och en teoretisk utgångspunkt i lärandet som ett relationellt potentialitetsfält (Dahlberg \& Elfström, 2014:282) har jag som forskare försökt att händelsefiera tillvaron genom att flytta fokus från det förgivettagna till det som varit i tillblivelse (jfr. Unga, 2013:32). Detta har resulterat i ett rikt datamaterial då det i förväg varit svårt att avgöra vad som var viktiga kopplingar i relation till studiens syfte.

I linje med god forskningssed (Vetenskapsrådet, 2017) har riktlinjer och krav för information och samtycke beaktats. Hänsyn har tagits till deltagarnas integritet, inga känsliga personuppgifter har 
behandlats och allt datamaterial har avidentifierats. Vid observations-tillfällen med film- och ljudinspelning har barnens och pedagogernas samtycke explicit efterfrågats.

Med forskningsfrågans fokus på framväxten av barnens frågor var det viktigt att redan i urvalet vara uppmärksam på att studien förlades vid verksamhet med ett utforskande arbetssätt där barnens frågor verkligen stod i centrum. Inför projektstarten fick jag ta del av pedagogernas syftesförklaring:

- Att samlas kring ett gemensamt ämne

- Att väcka barnens intresse och nyfikenhet och samla barnens erfarenheter och relationer till ämnet

- Att få möjlighet att "skärpa ögat” genom att undersöka och titta närmare på det som rör projektet

- Att ge barnen olika verktyg t.ex. bildarbete, konstruktion, lera m.m., så att alla får möjlighet att hitta ett uttryckssätt

- Att erbjuda ett arbetsklimat där alla făr möjlighet att dela med sig av sina teorier

- Att få möjlighet att dela med sig av sin kunskap och därmed få ett gemensamt lärande

- Att kunna ställas inför problem och få möjlighet att tillsammans hitta en lösning

Trädprojektet avslutades med en hel dokumentationsvägg där en gemensam målning över ett träds liv åskådliggjordes, besökare guidades runt och barnens plantor erbjöds till försäljning. Då FY:s projektavslut uppvisade en samlad, om än inte fullständig, bild av de frågor som uppstått och utforskats under läsåret utgör avslutet utgångspunkten för kartläggningen i denna artikel. Under gåturer med barnen i den avslutande utställningen kunde fördjupande frågor kring trädprojektet ställas. För att synliggöra kopplingar kommer utöver projektavslutet även nedslag från projektprocessen att lyftas fram i form av utvalda delar av deltagande observationer, fokussamtal och barnens alster. Urvalet grundas i syftet att studera meningsskapandet som växer fram i barnens möten med träd samt hur det möjliggörs genom ett utforskande arbetssätt. Då detta är en empiridriven, kvalitativ studie innebär det att de empiriska exemplen inte ska ses som representativa eller generaliserbara. Idén är att belysa såväl frågornas framväxt som vad de utmynnat i, dock inte alltid i en linjär ordning.

\section{Kartläggning}

Med utgångspunkt från begreppet lärandet som ett relationellt potentialitetsfält kan studien ses som en kartläggning av barns utforskande under ett trädprojekt. Vid en kartläggning går alltid något oundvikligen förlorat; skulle en karta återge allt i skala 1:1 vore det inte längre en karta. Avgränsning och fokusering är därför nödvändig vid datagenerering och analysprocess, och i denna artikel riktas fokus mot de problemfält som uppstått. Kartläggningen är därmed ingen exakt avbildning av det som skett under trädprojektet utan kan snarare ses som ett försök att förmedla en analyserad karta över valda delar av den generade empirin. Den är inte heller jämförbar med en ordinär fysisk karta då den liksom rhizombegreppet rymmer ett "mitt-i" med hög intensitet med mångfaldiga kopplingar utan början eller slut. Kartan är således öppen till sin struktur, den är "sammankopplingsbar i alla sina dimensioner, nedmonteringsbar, omvändbar, ständigt förmögen att motta modifikationer" (Deleuze \& Guattari, 1980/2015:31). Detta gör det möjligt att koppla samman eller kombinera kartor och i förlängningen även att arbeta i flera skikt. Själva kartläggningsprocessen och den öppenhet som Deleuze och Guattari menar att kartan omfattar blir än tydligare i det engelska begreppet mapping där den pågående processen och de multipla kopplingarna inryms. Förhoppningen är att den sammanställda kartan över datagenereringen kan förmedlas och kommuniceras utan att göra avkall på varken rörlighet eller systematik (jfr. Cosgrove, 1999; Dodge, Kitchin \& Perkins, 2009).

Kartläggning (mapping) är en metod som använts inom forskning knuten till förskola/skola (se Aronsson, 2019; Hermansson, 2013; Sellers, 2015; Unga, 2013). Utifrån en kartläggning av ungdomars konversationer kring den egna och samhällets framtid har Johansson (2015) formulerat en "tillblivelsens pedagogik", där det befintliga ifrågasätts och plats ges till det odefinierade och ännu-icke-sedda att träda fram. Mapping framhålls som en metod där tillblivande och potentialitet kan synliggöras. 


\section{FÖRSKOLEKLASS FY:S PROBLEMFÄLT}

De empiriska resultaten framställs som ett problemfält, trots vetskapen om det omöjliga i att särskilja och kategorisera en ständigt pågående process som ett projektarbete innebär. FY:s problemfält presenteras inte linjärt utan "börjar i slutet" med vårterminens projektavslutning varifrån barnens frågor och provisoriska teorier under hela projekttiden nystas fram.

Vid FY:s projektavslutning täcker en kollektiv bild av ett träd och dess omgivning en hel klassrumsvägg. En del av väggen upptas av barnens nedtecknade teorier och alster kring trädets liv (se figur 1-3, 4-5). På ett bord intill står lerstudier av frön, i ett hörn finns en knopputställning med fjärilslarver under utveckling och i ett annat hörn pågår en utställning om fåglar. Plantförsäljning, guidade visningar, pedagogisk dokumentation och en rullande bildvisning erbjuds besökare av öppet-hus-evenemanget.
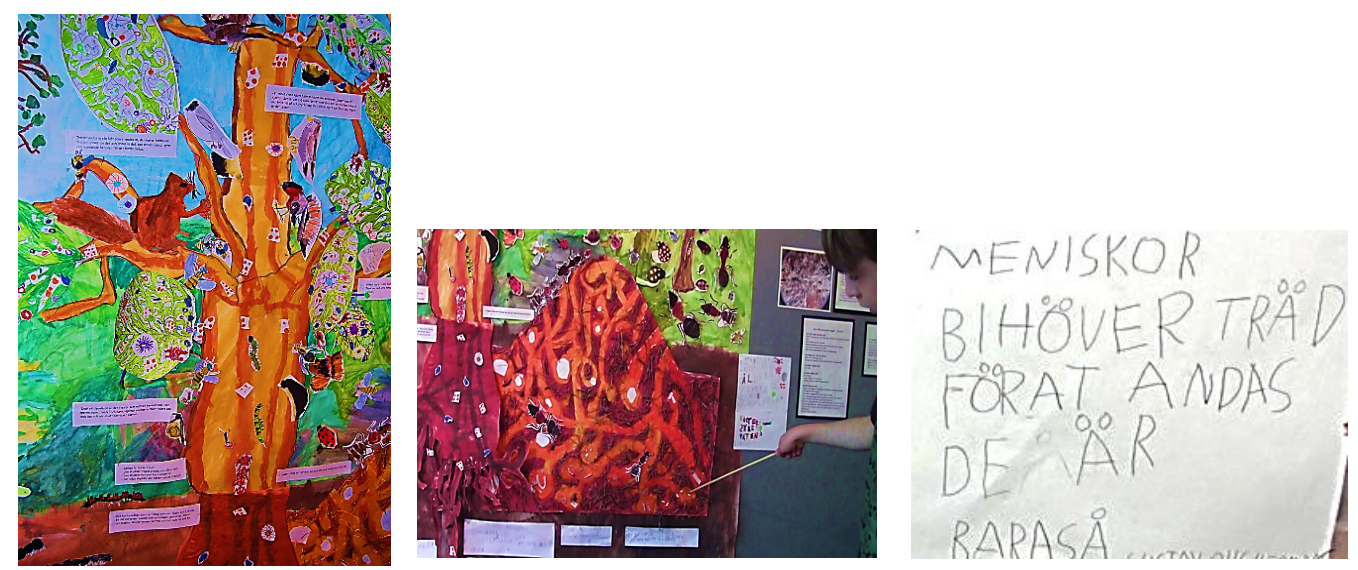

Figur 1-3. Delar av FY:s kollektiva presentation av trädet: trädbilden, myrstacken (detalj) och en text om träd.

Under en gåtur vid vårterminens sista dag visar ett av barnen, Sandro, mig runt. Han startar med trädbilden och avslutar vid fågelutställningen och berättar detaljerat om de olika djuren som lever nära trädet, särskilt fåglarna. Han beskriver hur sniglar, maskar, fjärilar och nyckelpigor lever i trädets närhet. Vid myrstacken visar han myrornas olika utvecklingsstadier: "Myror har också larver och det är alltså de här [pekar på myrlarverna i myrstacken] och myrpuppor och det är alltså de här [pekar på pupporna], där... här är larver alla. Och äggen, det är de här”. På frågan om hur de olika delarna hänger ihop svarar Sandro först på en allomfattande nivå, men återvänder strax till mer detaljerade beskrivningar:

Sandro: Alltså, vi behöver ju träd för att... annars kan vi ju inte andas. Det är träden som gör så att... det är träden som ger luft. Och det är såhär: djuren behöver också träden, vi också. För det är så att... det är därför... ”Hur det här hänger ihop?” - ja då är det så att vi behöver träden, att bygga bo och göra allt möjligt och gömma sig... och lägga mat nånstans... som ekorrar... eller klättra eller äta på... eller blad är också lite mat till larver och alla andra insekter. Här är larverna, här och här... det var en larv, här är en fjärilslarv, där och där och där någonstans [pekar på larverna], där och sen... var är den då? Här... och där har vi fjärilspuppor och det är de här. Och där är en till [...] Alltså det är först larver, alltså det är fjärilslarver, först är de larver sen gör de alltså nät så att det blir en puppa, alltså nätet är liksom en puppa. Sen spricker pupporna, så då kommer fjäril... då förvandlas larven därinuti puppan till en fjäril och sen kommer den ut. 
Alldeles i starten av trädprojektet samtalade barnen ofta om träden i relation till sina egna liv, som när de vid en samling i början av höstterminen diskuterade trädens familjeliv:

Hedda: Samma sorts träd tillhör samma familj.

Ville: Jag tror familjen kan vara ungefär åtta träd.

De gjorde även jämförelser mellan träden och sina egna kroppar:

Milo: Löven är trädens hår.

Ebba: Löven är händerna.

Liv: Bladen är hår. En del träd har hål, de är som munnar.

Leya: Rötterna är som ben. Kådan är som blod.

Otto: Barken är som skinnet.

Lukas: Jag tror att trädets frö är som hjärtat.

Ett noggrant utforskande av trädets alla delar påbörjades: blad, frukter och nötter, barken på olika träd jämfördes, liknelser och skillnader mellan den egna kroppen och trädets undersöktes. Förskolläraren Nina beskriver i en processberättelse hur frågor som uppkommit diskuterats och utforskats vidare.

Nina: Barnen sätter det här snabbt i relation till sig själva och sina egna kroppar och ganska snabbt börjar de beskriva. När vi frågar "varför har träden bark?” då är ju det: "barken är trädens hud", trädens skinn som skyddar dem. "Rötterna är trädens fötter" men också trädens munnar eftersom de säger - och det här skrattar de ju åt att det är fötter och munnar samtidigt eftersom de tar upp vatten och näring - "då tänker de med rötterna!". Och "grenarna är armarna” och "löven är håret”. Och där har vi väl varit ganska länge i att man relaterar till kroppen. Igår så frågade vi om löven, är det liksom så att de är håret, för vi har ju samlat löv nu eftersom de skiftar färg och det är ju jättespännande. Och då var det någon som sa: ”Nä, löven är inte bara hår. Utan träden tar upp, andas in våran gamla luft. Luften vi andas ut tar träden upp med bladen och så andas den ut frisk luft." "Jaha”, sa jag, ”är det så det är?". ”Ja", säger Valter, "de andas in koldioxid och andas ut syre, och vi behöver syre för att vi ska kunna leva." Och det blir ju jätte-jätteintressant. Sen säger Lukas så här: "Det här med att träden skiftar färg...", och det här kommer inom loppet av fem minuter. Så säger Lukas: "Jomen förstår du, i löven när de ändrar färg så finns det nånting som heter klorofyll, det är en slags celler och på hösten då lossnar klorofyllet från bladen". Och då säger jag: "Men var tar det vägen då?" "Det kanske hoppar till några andra blad eller så ramlar det ner på marken.” Och då frågar jag: "Kan vi gå ut då och samla klorofyll under träden?” ”Nä, du vet att de där cellerna är så små så de studsar iväg, så de ser man inte" [skratt]. Ja, så nu är den teorin, det här med att de [löven] skulle vara någon sorts dekorativt hår på träden, det är avfärdat, de fyller någon sorts funktion. Men sen var det något utav barnen som sa något intressant när vi pratade om det här med löven; som säger att "Vad bra att vi har träd!" och då är det ett barns som säger: "Och vilken tur att träden har oss! Om de måste andas in våran gamla luft, så är det ju tur att inte människorna dör ut, för då făr de ju ingen gammal luft” [skratt]. Så där ser man det där ömsesidiga beroendet liksom, att träden är beroende av oss och vi är beroende av dem. Och jag tycker att det blir fler och fler sådana kopplingar, att barnen kopplar ihop våra ömsesidiga beroenden av varandra... och tänker runt det. Och då kan man tänka sig att först börjar de i det lilla perspektivet, att de börjar prata om och jämföra med sina egna kroppar och beskriver trädet som en kropp, men sen så börjar de se att det är ju andra funktioner - men det finns verkligen ett beroende.

Barnen arbetade senare under hösten i par med två- och tredimensionella lerstudier för att ytterligare konkretisera sina teorier kring trädens innanmäte (se figur 4-6). 

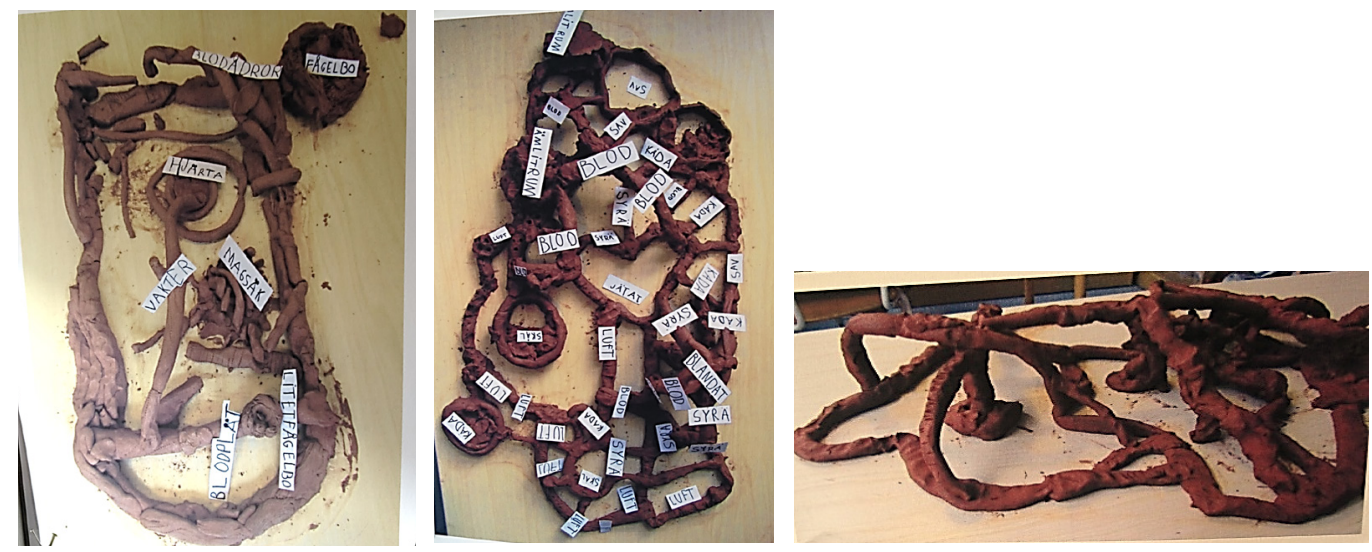

Figur 4-6. Trädets inre system gestaltas i lera, där organ som hjärta och magsäck lokaliseras, men även sav, kåda samt vakter, fägelbon och ett hemligt rum.

Barnens teorier kring trädets hjärta diskuterades vidare: Var finns hjärtat? I fröna? Under barken? Hypoteserna prövades, en rotvälta i skogen undersöktes noggrant för att finna hjärtat. I en senare processberättelse beskriver förskolläraren Nina barnens fortsatta diskussioner och utforskandet av trädets hjärta:

Nina: När vi har varit i skogen så har vi karvat med kniv och med stämjärn i omkullfallna träd för att hitta det här hjärtat. Då har vi vuxna ställt oss till förfogande och varit barnen till hjälp med att försöka hitta hjärtat. Och det har ju inte gått något bra, så vi var ju tvungna att börja sammanfatta det här "hur går det med hjärtat?". Det satt vi och pratade om vid en samling en morgon, sista mars var det, och då konstaterade barnen att "nää, vi har ju inte hittat något hjärta". Men vi skulle ut den måndagen och leta en gång till i alla fall hade vi bestämt. Då när vi sitter där och pratar innan vi går iväg så säger Jack så här: "Men tänk om träd är som maneter, för de har ju varken hjärta eller hjärna men dom lever och äter i alla fall, så det kanske är något annat...”. Och då kände vi att... ja, vi gick i alla fall ut... Vi bara lyssnade och sa ”Ja, tänk om det är så Jack". Och så gick vi ut och så hade vi med oss stämjärn och så karvade vi i trädet en sista gång. Och så gav vi upp, vi konstaterade hela klassen att "Nä, vi hittade inget hjärta". Och så började vi prata om det här som Jack hade sagt och då var barnen inne på att de kanske äter med rötterna och det här med bladen, då kände vi att då var det faktiskt läge att presentera fotosyntesen för barnen.

De olika teorierna kring trädets hjärta fortsätter dock att diskuteras ända till trädprojektets avslutning. När jag under gåturen med Sandro vid projektavslutet återkommer till frågan om de hittat trädets hjärta är han fortfarande osäker:

Sandro: Ehh, ja, vi hittade det. Nä, vi hittade inte trädets hjärta... fast de har... ja alltså vi hittade trädets hjärta, det som... Här - vi har tagit bilden... här... men vi hittade en [ohörbart] som vi tog av alltså, tog av sen... det där är lite av hjärtat [pekar mot trädkärnan på en bild av genomskärningen av ett träd].

Bodil: Mmm.

Sandro: Vi tog bort så blev det bara rödare och rödare.

Bodil: Hur visste ni att det var hjärtat då?

Sandro: Vi trodde... men, det kan vara trädsvampar... men jag vet... vi visste... jag vet inte, men det kanske är... 
När jag senare samma dag gör en gåtur med fyra flickor, Maja, Hedda, Malva och Nelly, inleder Maja presentationen av trädväggen med att summera processen kring hypotesen om löven som trädets hår: "Vi har gjort ett träd för att vi undrade hur det fungerade och vi har gått i skogen och tagit med lite grenar och undersökt dem. Man kan tro att trädens löv är trädens hår, fast det är det inte - det är deras kraftkälla.” Barnen har utifrån sin provisoriska teori utforskat frågan vidare.

Att bredda och samtidigt fördjupa frågeområdena var en utmaning för pedagogerna som funderade kring hur projektet och den utforskande processen skulle kunna fortleva under de vintermånader träden vilade. Vid en samling frågade pedagogerna barnen hur trädprojektet kunde gå vidare, varpå barnen föreslog att de kunde undersöka vilka djur som behöver träd. Tillsammans kom man överens om att gå ut på spaning efter djur som levde i den lilla skogen nära skolan. Förskolläraren Nina beskriver i en processberättelse vad som hände:

Nina: Och då var det Frej och Moltas som började prata om "Kan vi inte titta på vilka djur som behöver träd?" Och då frågade vi, det var ju jättespännande, "hur gör vi då?”. "Vi går ut i skogen och tittar efter djuren" och det tyckte vi ju var ett fantastiskt förslag och pratade om vad vi måste tänka på då. ”Jo, vi måste ju vara väldigt tysta och vi får smyga och så". Och så sa vi att vi anade att det kan ju bli ett svårt uppdrag att hitta djuren. "Men om vi inte hittar just några djur, kan vi på något annat sätt koppla djur och träd? Då kom de på, det var ju snö fortfarande, "vi kanske kan hitta spår i snön”. Och då sa vi det att vi kan titta efter det också, vi tittar både efter djur och efter spår i snön. Så vi gick ut i skogen den förmiddagen och det var helt fantastiskt när vi alla såg saker som vi normalt sett missar: rådjurslegor och... vi hittade spillning efter både rådjur och hare och precis intill där vi hittade harspillningen så hittade vi också där haren hade kissat och det hade vi aldrig någonsin sett förut. Och vi följde spår, harspår och hade mycket diskussioner kring "åt vilket håll går spåren?”, ”baktassar, framtassar först eller sist?”. Och vi följde rådjurens vandringar och vi hittade små spår efter fåglar på frusna pölar i skogen och funderade mycket över vad de gjort där och varför var det så mycket spår just där det var en liten öppning i vattenpölen - "vad beror det på?”. Det var faktiskt ett otroligt roligt arbetspass!

Ett samtal kring djurens livsbetingelser under vintern följde: hur klarar sig djuren runt träden under vintern? Barnen förkovrade sig, närstuderade djuren och målade av dem (se figur 7-9).
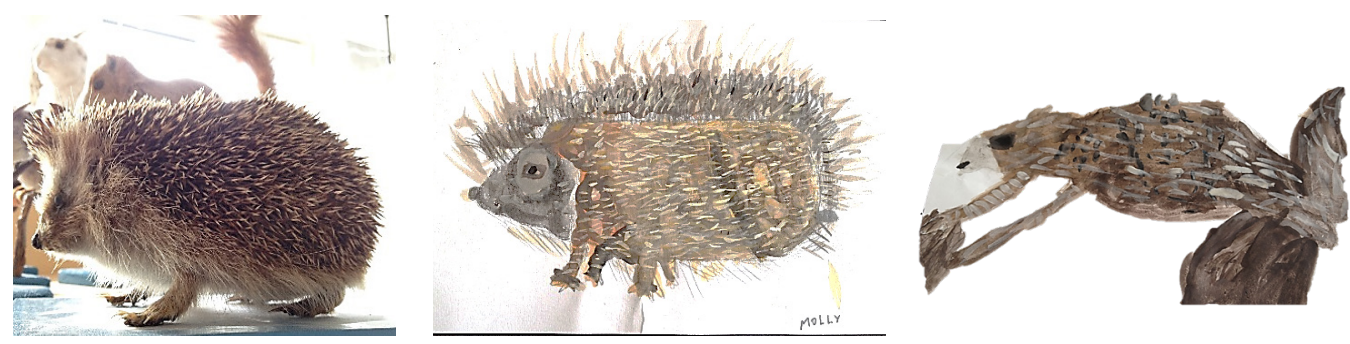

Figur 7-9. Exempel på barnens detaljrika närstudier av uppstoppade djur, igelkott samt ekorre $i$ vinterpäls.

Fågelspåren kring vattenpölen under spårspaningen framkallade specifika frågor kring fåglar och deras speciella livsvillkor. Barnen började med att skissa olika fågelarter för att sedan måla av dem. Två pojkar, Sandro och Sam, gjorde en fågelbok, de studerade hur fåglar avbildades i fågelböcker och producerade sedan egna stiliserade bilder av många olika fåglar i ett snabbt tempo (se figur10-11). 

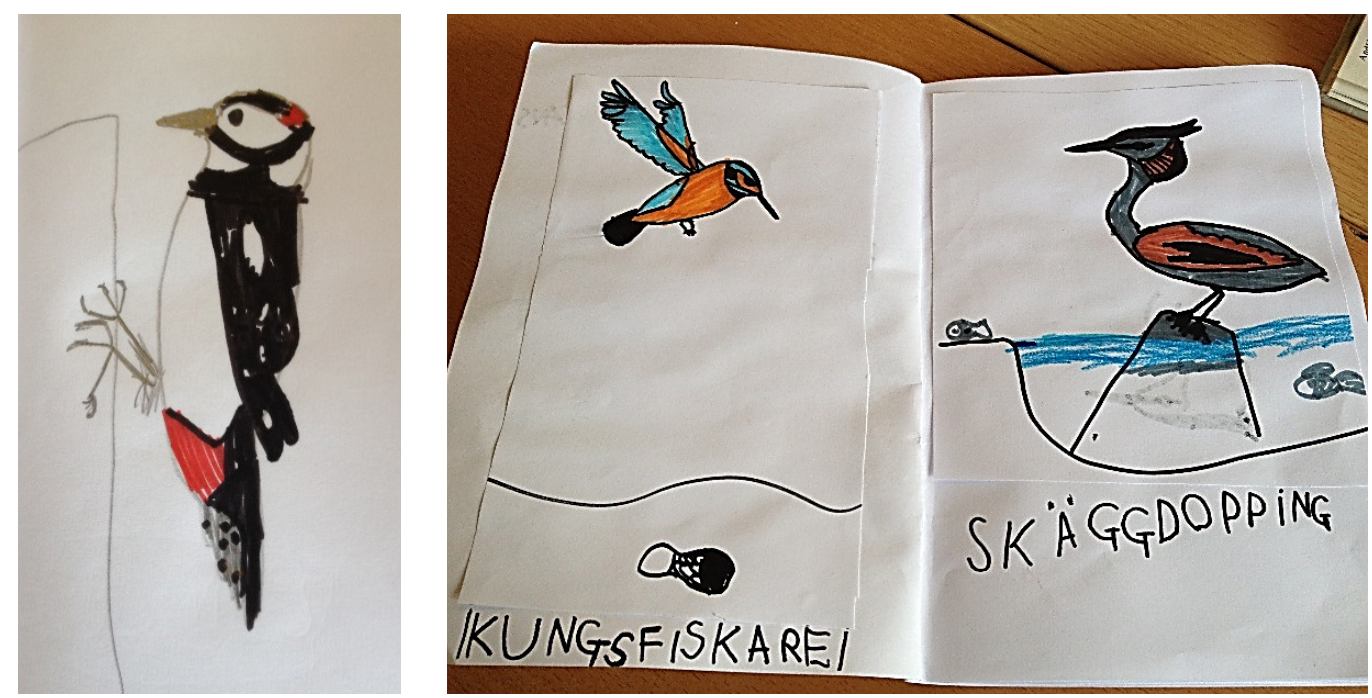

Figur 10-11. Bilder ur Sandros och Sams fågelbok: större hackspett, kungsfiskare och skäggdopping.

När jag under gåturen vid vårterminens slut frågar Sandro var fågelboken tagit vägen ser han frågande ut: "Vilken fågelbok?”. Han letar i sin och Sams lådor, men hittar den inte: ”Den är nog hemma... eller så har jag slängt den eller något sånt...”. Den försvunna fågelboken kom även upp senare i ett av fokussamtalen med pedagogerna där Nina menar att fågelboken snarare var medel än mål:

Nina: Och han [Sandro] jobbade ju hårt med att finslipa sitt redskap - att teckna fåglar. Och gick ifrån att först forma näbbar och klor och ben och fjädrar, men sen kom han ju in på fjäderdräkternas färgskiftningar. Alltså han höll verkligen på att finslipa sitt redskap: hur fåglar ser ut, hur färgerna sitter, hur färgskiftningarna syns - skimrande fåglar. Kommer ni ihåg duvorna han gjorde med alla regnbågens färger på vingarna? Jag tror inte heller att han tyckte att han skapade någon slags fågelbok här, utan det var bara en radda med övningar - på väg någonstans.

I det avslutande fokussamtalet återkom Nina till Sandros fågelintresse ännu en gång och berättade hur han visat henne runt bland fåglarna och deras bon på skolgården:

Nina: Det var ju inte bara ett intresse för att teckna. Jag glömmer aldrig när vi var ute på våren och fåglarna hade börjat bygga bon och han [Sandro] visade mig alla fågelbon vi hade på skolgården, som jag inte hade en aning om. Han kunde peka ut "där är björktrast och där är björktrast" och vi gick runt och det var precis som han sa. Vi kunde se ungarna, ”ser du inte, Nina, stå här får du se, se ungarna när de kommer och matar. Och där borta har skatorna bo på granntomten och skatorna brukar komma hit och bråka med björktrastarna”. Och då tänker jag så här - vad har han gjort hela rasterna, har han gått här och studerat fåglar?

En annan fråga som kom och gick under projekttiden handlade om hur träd uttrycker sig och kommunicerar med andra träd:

Nina: Sen har de pratat om... Jack satt en morgon och tog upp att träd faktiskt kan uttrycka känslor, rädslor, att ett träd kan skrika. Men att det är ingenting vi kan höra, men träd kan faktiskt skrika och de kan också kommunicera med andra träd. Och det här blev ju lite fnissigt runtomkring, för det var några som tyckte att "men vadå träd kan skrika?". 
När Nina, som började senare den dagen, fick höra om samlingens diskussion kunde hon bekräfta att det finns forskning som styrker det han hävdat under samlingen.

Nina: När jag kommer och de berättar den här situationen, att Jack blev ganska ledsen därför att det var ingen som tog honom på allvar och Lena och Ulla visste inte riktigt heller riktigt hur de skulle gå in i den här teorin och då slår det mig att det här har jag sett. Jag har sett ett vetenskapsprogram som handlar om... inte att man kunde mäta det i ljud, men däremot att man kunde se ljusfenomen runt träd på väg att huggas ner eller skadas - att de faktiskt reagerar. Och jag minns ju inte själv om det är så att man mäter ultraljud eller vad det är som händer. Men jag kunde ju då direkt samlingen efter bekräfta att "det här känner jag igen Jack, det du berättar" och så börja vi prata om att det finns ljudfrekvenser som vi människor inte kan uppfatta. Och då har ju barnen varit med om att det finns visselpipor som man visslar på hundar med, som vi inte hör men hunden hör direkt. Och då började vi prata om att det finns faktiskt ljud som våra öron inte uppfattar, men som andra kan uppfatta och det här är kanske ett sånt ljud. Så vi kunde ju ändå... det var ganska skönt för honom.

Frågan om hur träden kommunicerar återkom sedan under hela projektets gång.

\section{KARTLÄGGNING AV FY:S PROBLEMFÄLT}

När FY:s problemfält kartläggs utifrån lärandet som ett relationellt potentialitetsfält synliggörs barnens frågor och provisoriska teorier. Genom att identifiera kopplingar som uppstår mellan träden och den egna kroppen, familjekretsen, kring trädens inre och yttre system samt trädens kommunikation framträder hur frågorna expanderar och komplexiteten ökar. I starten av trädprojektet utgår barnen från tidigare erfarenheter av det egna familjelivet som kopplas direkt till trädens familjebildningar, frågor kring hur trädfamiljer kan se ut och hur stora de kan vara uppstår. Även kopplingarna till den egna kroppen är tydliga och därifrån startar deras konkreta undersökande: Är bladen trädets hår, rötterna trädets fötter, barken skinnet? De jämför synliga likheter och skillnader mellan olika trädarter, men funderar också över trädets inre mer osynliga funktioner: Har trädet ett hjärta? Blodådror? I lerstudierna konkretiseras trädets innanmäte; här finns också ett hemligt rum, vilket kan ses som exempel på hur barnen bygger in ännu obesvarade frågor i sina pågående undersökningar. Förskolläraren Nina lyfter i processberättelsen fram hur barnens frågor följs upp, utforskas och fortlöpande diskuteras vid de gemensamma samlingarna. Barnens teorier prövas: frågan om trädet har ett hjärta undersöks grundligt och de flesta barnen är vid projektets slut inne på Jacks linje att hjärtat inte är en förutsättning för liv, även om några barn fortfarande håller kvar frågan. Den trädforskning som nyligen funnit att träd har en form av regelbunden puls (Zlinszky \& Badford, 2018) påminner om att trädens inre system är komplexa, att inte alla forskningsfrågor är besvarade och att nya rön ständigt publiceras. Under processen uppstår inte någon motsättning mellan frågor och svar, frågorna driver projektet vidare samtidigt som svaren ger bränsle till fortsatt utforskande och fördjupning. Ett exempel är Majas kortfattade summering av en lärprocess där kopplingen löv-hår utvecklats vidare till teorin om löven som trädens kraftkälla efter många timmars utforskande, estetiskt gestaltande, fördjupning i fotosyntesen samt långa diskussioner kring bladens funktion.

Barnens förslag om vinterspaning ger kopplingar till djur som lever nära träden. Ett ingående studium av djurens livsbetingelser startar och barnen avbildar djur i snabba skisser och detaljerade målningar. Fåglarnas spår kring den frusna vattenpölen blir en koppling som ger Sandro och Sam en egen fördjupning kring fåglar. Pojkarna arbetar målmedvetet med sin fågelbok under flera veckors tid. Vid projektslutet är dock fågelboken försvunnen, Sandro letar men hittar den inte. Förskolläraren Nina menar att boken i sig inte var målet, tecknandet var snarare ett övande. När Sandro senare guidar Nina bland skolgårdens fågelbon framträder dock hans iakttagelser och utförliga kunskaper om björktrastars och skators vanor och livsmönster tydligt.

När våren kommer följer barnen hur värmen väcker träden till liv steg för steg. De följer knoppsprickningen dag för dag, planterar frön och närstuderar småkryp som vaknar i trädets närhet. Kopplingar 
till småkrypen och mikrolivet framträder. Barnen följer på nära håll tistelfjärilens utveckling från ägg till fjäril och myrornas vandringar och under gåturen sammanfattar Sandro fjärilens metamorfos och myrornas utvecklingsstadier när han presenterar trädbilden.

Barnens ställer avancerade frågor kring trädens inre och yttre kommunikation och även om deras provisoriska teorier inte alltid är naturvetenskapligt belagda så är de hela tiden, likt forskarna, öppna inför att få veta mer kring hur träden kommunicerar (jfr. Gagliano et al., 2017; Schöner et al., 2016; Simard, 2012). Under en samling tar Jack upp frågor kring trädens kommunikation och känsloliv vilket förskolläraren Nina fångar upp i en dialog och frågorna fortsätter sedan att diskuteras under vårterminen. Träds kommunikation är tätt förknippat med ett utbyte och ett beroende av andra levande varelser (Mancuso \& Viola, 2015) och nya kopplingar till hur ljud och signaler kan uppfattas av olika mottagare växer fram. Texten på dokumentationsväggen konstaterar att utbytet är ömsesidigt: "människor behöver träd för att andas - det är bara så". Bakom påståendet ligger ett fördjupat utforskande kring bladens funktion och fotosyntes. Nina lyfter i processberättelsen att utforskandet som börjat med jämförelser med den egna kroppen utvecklats till att se mer komplexa funktioner och ekologiska samband, barnen har fått syn på det ömsesidiga beroendet. Sandro berättar under gåturen om hur människor och djur behöver träd för att tillgodose sina basala behov som andning, föda, skydd.

\section{SAMMANFATTANDE DISKUSSION}

Att utforska träd i en antropocen tidsålder är ett sätt att närma sig frågor om växters liv och deras betydelse för oss människor och därigenom aktivt motarbeta en eventuell oförmåga att se och värdesätta växter, s.k. växtblindhet (jfr. Nyberg et al., 2019; Sanders, 2019). Vid barnens utforskande av trädens livscykel i relation till årstiderna uppstod under projekttiden ständigt nya kopplingar som i sin tur öppnade för ytterligare frågor. Problemfältet kom efterhand att utvecklas till mer komplexa ekologiska och etiska frågeområden. När barnens meningsskapande kartläggs kan såväl målstyrda som icke målstyrda processer följas. Mer oförutsedda kopplingar blir synliga, såsom spaningen efter trädets hjärta eller det plötsliga fågelintresset. Barnens frågor dokumenterades och togs på allvar, deras teorier prövades och gav energi till vidare diskussioner om trädets inre, vad växtkraft egentligen innebär och hur det ömsesidiga beroendet mellan träd och djur kan se ut.

I kartläggningen framkommer, i linje med tidigare forskning kring hur barn gör naturvetenskap (Caiman, 2015; Areljung, 2017), att barnens utforskande går från jämförelser mellan den egna kroppen och trädet, över form och funktion, mot mer komplexa resonemang kring relationer och varför-frågor som rör ekologi och hållbarhet (jfr. Caiman \& Lundegård, 2015; Sundberg et al., 2019). Under projektets gång omsatte och kommunicerade barnen sina nyförvärvade kunskaper i nya sammanhang vilket visar på ett förändrat kunnande; som när Sandro vid vårens ankomst tog med Nina på fågelspaning runt skolgården och när barnen vid projektavslutet guidade besökande genom trädutställningen. Kartläggningen visar på att barns vardagliga möten med omvärlden kan knytas direkt till omgivande ekologiska sammanhang (jfr. Rautio, 2013; Rautio et al., 2017) och öppna för relationella ingångar till miljö- och hållbarhetsfrågor (jfr. Halvars-Franzén, 2010; Taylor, 2017).

När barnen i projektet använder estetiska uttryck för att formulera och kommunicera sina frågor och teorier genom att visa hur träd ser ut inuti i lerbyggen eller teckna sina teorier kring växtkraft, framstår deras meningsskapande tydligt. Vid ett utforskande arbetssätt, där ett sinnligt närmande och experimentellt förhållningssätt ges plats genom estetiken, kan en ökad känslighet och nya kreativa lösningar utvecklas (Dahlberg et al., 2016). Det rhizomatiska perspektivet i analysen synliggör hur barnen skapar mening utan att orsak-verkan-resonemang uppstår, vilket i förlängningen kan vara produktivt när det gäller att förebygga eventuella glapp som kan uppkomma mellan barnens ämnesinnehållsliga frågor och pedagogernas förskoledidaktiska syften. 
Trädprojektet har växt fram där ett utforskande arbetssätt varit ett medvetet val från pedagogernas sida. Ett formulerat projektsyfte har riktat och avgränsat möjliga fråge- och problemställningar som kunnat undersökas utifrån ett ämnesinnehållsligt fokus på träd. Pedagogernas förskoledidaktiska strategier har samtidigt gett utrymme för barnens provisoriska teorier (jfr. Areljung, 2017; Hedges, 2014), genom att identifiera, utmana och undersöka dem vidare tillsammans med barnen. De har förkovrat sig, ställt produktiva frågor, erbjudit utforskningsbara material och miljöer samt bidragit med sitt engagemang och didaktiska kunnande. Då intensiteten i barnens kopplingar tillvaratagits har komplexa frågor kring ekologi och hållbarhet utforskats utifrån barnens perspektiv och risken för normering eller klimatoro minimerats. Detta kan ses som möjlighetsvillkor för ett utforskande projekt där barns frågor är drivkraften vilket kommer att behandlas mer utförligt i kommande utsnitt av denna studie.

\section{REFERENSER}

Areljung, S. (2017). Utanför experimentlådan: kunskapsproduktion, tid och materia i förskolans naturvetenskapsundervisning. Diss. Umeå: Umeå universitet.

Areljung, S. \& Kelly-Ware, J. (2016). Navigating the risky terrain of children's working theories. Early Years, (37)4, 370-385. DOI: 10.1080/09575146.2016.1191441

Aronsson, L. (2019). När förskolan möter neurovetenskap. Kunskapsteoretiska möten i teori och praktik. Diss. Stockholm: Stockholms universitet.

Caiman, C. (2015). Naturvetenskap i tillblivelse: barns meningsskapande kring biologisk mångfald och en hållbar framtid. Diss. Stockholm: Stockholms universitet.

Caiman, C. \& Lundegård, I. (2015). Barns meningsskapande i ett projekt om biologisk mångfald och ekologi. NorDiNa, 11(1), 73-87.

Caiman, C. \& Lundegård, I. (2018). Young children's imagination in science education and education for sustainability. Cultural studies of science education, 13(3), 687-705.

DOI:10.1007/s11422-017-9811-7

Calvo, P., Gagliano, M., Souza, G. \& Trewavas, A. (2020). Plants are intelligent, here's how. Annals of Botany, 125(1), 11-28. DOI:10.1093/aob/mcz155

Clark, A., Flewitt, R., Hammersley, M. \& Martin, R. (Eds.) (2014). Understanding research with children and young people. Los Angeles, California: SAGE.

Cole, R. \& Malone, K. (2019). Environmental education and philosophy in the Anthropocene. Australian Journal of Environmental Education, 35, 157-162. DOI:10.1017/aee.2020.5

Colebrook, C. (2010). Gilles Deleuze: en introduktion. Göteborg: Korpen.

Cosgrove, D. (Ed.) (1999). Mappings. London: Reaktion.

Dahlberg, G. \& Elfström, I. (2014). Pedagogisk dokumentation i tillblivelse. Pedagogisk forskning, 4-5, 268-296.

Dahlberg, G., Olsson, L. \& Theorell, E. (2016). Discplacing identity - placing aesthetics: early childhood literacy in a globalized world. Discourse: Studies in the Cultural Politics of Education, 37(5), 717-738. DOI:10.1080/01596306.2015.1075711

Davis, K. \& Peters, S. (2012). Exploring Learning in the Early Years. Working Theories, Learning Dispositions and Key Competencies. In Kaur, B. (Ed.). Understanding Teaching and Learning: Classroom Research Revisited. Rotterdam: SensePublishers.

Deleuze, G. \& Guattari, F. (1980/2015). Tusen Platåer. Hägersten: TankeKrafts förlag.

Dodge, M., Kitchin, R. \& Perkins, C. (Eds.) (2009). Rethinking maps: new frontiers in cartographic theory. Milton Park, Abingdon, Oxon: Routledge.

Elfström, I. (2013). Uppföljning och utvärdering för förändring: pedagogisk dokumentation som grund för kontinuerlig verksamhetsutveckling och systematiskt kvalitetsarbete iförskolan. Diss. Stockholm: Stockholms universitet.

Gagliano, M., Ryan, J. \& Vieira, P. (2017). The Language of Plants: Science, Philosophy, Literature. University of Minnesota Press. 
Green, M. \& Duhn, I. (2015). The Force of Gardening: Investigating Children's Learning in a Food Garden. Australian Journal of Environmental Education, 31(1), 60-73. DOI:10.1017/ aee.2014.45

Halvars-Franzén, B. (2010). Barn och etik: möten och möjlighetsvillkor i två förskoleklassers vardag. Diss. Stockholm: Stockholms universitet.

Hammersley, M. \& Atkinson, P. (2019). Ethnography: principles in practice. London: Routledge.

Hansson, L., Löfgren, L. \& Pendrill, A-M. (2014). Att utgå från frågor och situationer i förskolans vardag: Vilket naturvetenskapligt innehåll kan det leda till? NorDiNa, 1O(1), 77-89.

Hedges, H, (2014). Young children's 'working theories': Building and connecting understandings. Journal of Early Childhood Research 12(1), 35 - 49. DOI:10.1177/1476718X13515417

Hedges, H. \& Cooper, M. (2017). Collaborative meaning-making using video footage: teachers and researchers analyse children's working theories about friendship. European Early Childhood Education Research Journal, 25(3), 398-411. DOI:10.1080/1350293X.2016.1252153

Hermansson, C. (2013). Nomadic writing: exploring processes of writing in early childhood education. Diss. Karlstad: Karlstads universitet.

Johansson, L. (2015). Tillblivelsens pedagogik: om att utmana de förgivettagna: en postkvalitativ studie av det ännu-icke-seddas pedagogiska möjligheter. Diss. Lund: Lunds universitet.

Mancuso, S. \& Viola, A. (2015). Brilliant Green: the surprising history and science of plant intelligence. Washington, Covelo, London: Island press.

Nyberg, E., Brkovic, I. \& Sanders, D. (2019). Beauty, memories and symbolic meaning: Swedish student teachers' views of their favourite plant and animal. Journal of Biological Education. DOI:10.1080/00219266.2019.1643761

Olsson, L. (2009). Movement and experimentation in young children's learning: Deleuze and Guattari in early childhood education. London: Routledge/Taylor \& Francis Ltd.

Olsson, L. (2013). Taking Childrens Questions Seriously: the need for creative thought. Global Studies of Childhood, 3(3), 230-253.

Rassmann, S. \& Turlings, T. (2016). Root signals that mediate mutualistic interactions in the rhizosphere. Plant Biology, 32, 62-68. DOI:10.1016/j.pbi.2016.06.017

Rautio, P. (2013). Children who carry stones in their pockets: on autotelic material practices in everyday life. Children's Geographies, 11(4), 394-408. DOI:10.1080/14733285.2013.812278

Rautio, P., Hohti, R., Leinonen, R-M. \& Tammi, T. (2017). Reconfiguring urban environmental education with 'shitgull' and a 'shop'. Environmental Education Research, 23(10), 1379-1390. DOI: $10.1080 / 13504622.2017 .1325446$

Sanders, D. (2019). Standing in the shadows of plants. Plants, People, Planet. 2019(3):130. DOI:10.1002/ppp3.10059

Schöner, M., Simon, R. \& Schöner, C. (2016). Acoustic communication in plant-animal interactions. Plant Biology, 32, 88-95. DOI:10.1016/j.pbi.2016.06.011

Sellers, M. (2015)....working with (a) rhizoanalysis... and working (with) a rhizoanalysis. Complicity: An International Journal of Complexity and Education, 12(1), 6-31.

Simard, S. (2012). Mycorrhizal Networks and Seedling Establishment in Douglas-fir Forests. In Southworth, D. (Ed.). Biocomplexity of Plant-Fungal Interactions. West Sussex: Wiley \& Blackwell.

Skolverket (2017). Läroplan för grundskolan, förskoleklassen och fritidshemmet, 2011: reviderad 2017. Stockholm: Skolverket.

Somerville, M. (2018). Anthropocene's time. Educational Philosophy and Theory, 5o(14), 15841585. DOI:10.1080/00131857.2018.1461428

Sundberg, B., Areljung, S. \& Ottander, C. (2019). Opportunities for Education for Sustainability through multidimensional preschool science. NorDiNa, 15(4), 358-369.

Svedäng, M., Halvars, B., Elfström, I. \& Unga, J. (2018). Från komplexa frågor till ett konkret innehåll - hållbar utveckling ur ett förskoledidaktiskt perspektiv. Pedagogisk Forskning i Sverige, 13(3-4), 235-261. 
Taylor, A. (2017). Beyond stewardship: common world pedagogies for the Anthropocene, Environmental Education Research, 23(10), 1448-1461. DOI:10.1080/13504622.2017.1325452

Thomas, P. (2000). Trees: Their Natural History. Cambridge: Cambridge University Press.

Thulin, S. (2010). Barns frågor under en naturvetenskaplig aktivitet i förskolan. Nordisk barnehageforskning, 3(1), 27-40.

Unga, J. (2013). Det är en spricka i allt, det är så ljuset kommer in: matematik och förskolebarns experimenterande och potentialitet. Licentiatavhandling. Stockholm: Stockholms universitet.

UNESCO (2017). Education for Sustainable Development Goals: Learning Objectives. Retrieved February 27, 2020, from www.unesco.org

Vetenskapsrådet (2017). God forskningssed. Stockholm: Vetenskapsrådet.

Wandersee, J. \& Schussler, E. (1999). Preventing plant blindness. The American Biology Teacher, 61(2), 82-86.

Zlinszky, A. \& Barfod, A. (2018). Short interval overnight laser scanning suggest sub-circadian periodicity of tree turgor. Plant Signaling \& Behavior, 13(2), e1439655. DOI:10.1080/15592324.201 8.1439655 